\title{
Development and Testing of Manually Operated Row Crop Weeder
}

\author{
Ashebir Tsegaye $^{1} \&$ Abulasan Qabaradin ${ }^{2}$ \\ ${ }^{1,2}$ Oromia Agricultural Research Institute, Asella Agricultural Engineering Research Center, P.O. Box 06, Assela, Ethiopia.
}

DOI: http://doi.org/10.38177/AJBSR.2021.3107

Copyright: (92021 Ashebir Tsegaye \& Abulasan Qabaradin. This is an open access article distributed under the terms of the Creative Commons Attribution License, which permits unrestricted use, distribution, and reproduction in any medium, provided the original author and source are credited.

\section{ABSTRACT}

Weed control is one of the most difficult tasks on an agricultural farm. Three methods of weed control are commonly known in agriculture. These are mechanical, chemical and biological control. Mechanical weed control is easily adopted by farmers once they get convinced of its advantages. Various types of mechanical weeders have been developed. This project work involved the design and construction of mechanical weeder, after discovering that tools such as cutlass and hoes require high drudgery, time consuming and high labour force. As a solution to these problems, mechanical weeder was designed and constructed. The mechanical weeder was made of two implements attachment i.e. the primary cutting edge which is at the front to loose soil and the secondary cutting edge which is at the rear to perform cutting and lifting of weeds. The developed row weeder was tested in the wheat crop (variety Ogolcho) and the relevant data were collected and statistically analyzed. The weeding efficiency of the weeder was 84.67 and $81.67 \%$ respectively for sandy loam and clay loam soil types. The plant damage percentage of the weeder was 1.413 and $1.853 \%$ respectively for sandy loam and clay loam soil types. The weeder field efficiency was 82.79 and $81.72 \%$ at field capacity of 0.185 and 0.182 ha/day respectively at sandy loam and clay loam soils. The cost of operation was found 1,087.50, 1,762.50 and 1,712.5birr per hectare for weeder hoe and hand weeding methods respectively. The weeding cost of mechanical weeder was reduced by 38.30 and $36.50 \%$, respectively as compared to hoe and hand weeding methods. Thus the research work was carried out according to the predetermined objectives and the developed weeder was found to work satisfactorily requiring some further improvements as given in the suggestions for future research work.

\section{Introduction}

In Ethiopia, wheat is sown by different methods, broadcasting and row sowing depending upon the type of soil, topography of land and labours. In order to increase the productivity, efforts have been made through row sowing systems. With the advent of row sowing and the adoption of high yielding varieties interest in row seeding is seen among the farmers, which is not only maintain plant population but also offers additive advantages, such as intercultural operations and proper weed control. The weed control operations are mainly done by three methods such as hand weeding, hoe weeding and herbicides application. In hoe weeding, weeds are removed by using an indigenous tool, which is more effective but it is expensive, labour intensive as well as time consuming. Moreover, the labour requirement for weeding depends on weed flora, weed intensity, time of weeding, and soil moisture at the time of weeding and efficiency of worker (Datta el al., 1974). Nowadays herbicide usage is increasing. In view point of labour shortage circumstances; it is preferred as a quick and effective weed control method without damaging the plants. But, it has adverse effects on human health and environment. Today the agricultural sector requires non-chemical weed control that ensures food safety. Consumers demand high quality food products and pay special attention to food safety.

Through the technical development of mechanisms for physical weed control, it might be possible to control weeds in a way that meets consumer and environmental demands. Mechanical weed control reduces the chemical application involved in weeds control. Moreover mechanical weeder besides killing the weeds loosen the soil between rows thus increasing air and water intake capacity. But this method of weed control has received much less scientific attention compared to the other methods. As a result traditional tools, implements and methods are still used by majority of the farmers for weed control. Hand tools like hoe have been found effective but it is laborious 
and time consuming. Most of the weeding equipment's are indigenous developed and their dimensions and shapes are left to the skill and imagination of the local artisans and these tools are used in crouching and bending postures. In these postures, the energy consumption for a given load is 30-50\% more as compared to standing /sitting posture (Grandjean, 1988). Traditional weeders are used in undesirable postures according to ergonomic criteria; involve repetitive movement of body parts which may lead to musculoskeletal disorders (Rainbird and O'Neill, 1995).

In order to assess the possibility of mechanization of the weeding operation, single row weeder was proposed to be designed and developed considering the optimum shape, size and location of cutting blades, evaluation of its performance with other weeding methods in field conditions, optimization of dimensions of machine for better performance. The main objective is to design and fabrication of push and pull type weeder, while minimum damages done to wheat plants, cost effectiveness, easy manuvelling, low weight and fabrication by using available materials and easy maintenance are main features of this design. Here comes the relevance of mechanized weeding, which is not a huge time consuming and significantly improves weeding efficiency as well as the quality of weeding.

Therefore, the present work has been planned with the following specific objectives:-

1. To develop the single row crop weeder.

2. To evaluate performance of developed weeder and compare with other weed control methods.

\section{Materials and Methods}

This chapter deals with the design of a manual weeder. A prototype weeder was designed and developed to suit the Ethiopian farmer's conditions. The various factors involved in the design were operational safety, cost of production and availability of spare parts and ease of construction. The operation and adjustments were made simple so as to be used by the farmer. The weeder fabrication which include metal cutting, bending, shaping and welding was carried out at the workshop. The machine was tested at average human being speed on different types of soil. The material and methods about the development and testing of the weeder are discussed under the main headings mentioned below:-

\subsection{Machine Description}

The prototype weeder (Figure 1) consisted of frame, handle, cutting blade and drive wheels.

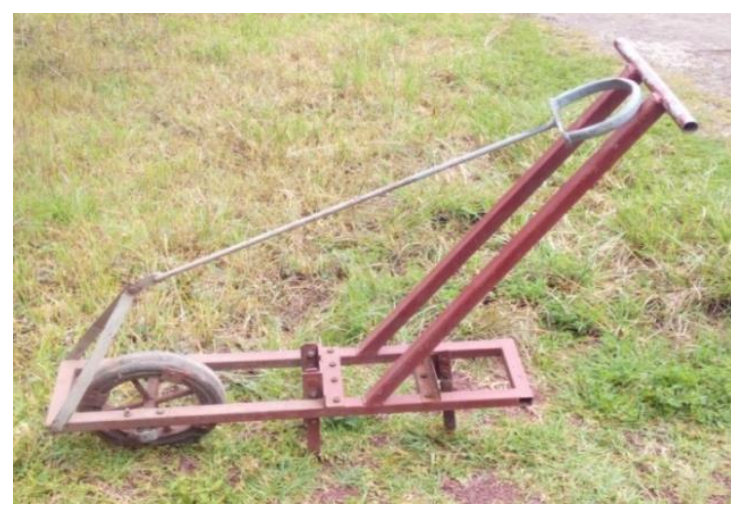

Fig.1. The developed row crop weeder 
To achieve the best performance from the weeder, the important factors were optimized by proper design and selection of the components required to suit the requirements of row crop weeder.

\subsubsection{Frame}

The frame is the most important part of this machine which is made of the square pipe as shown in Fig. 1. The top part of the frame holds handle and at the bottom the cutting blade is arranged and hitched with bolt and nut. The wheels are connected to the frame with the support of two pedestal bearings at both ends of the frame and with help of locking pins. The design of the frame was based on the design of components to be mounted on it

\subsubsection{Cutting blades}

Weeder blades are the parts which are directly having an interaction with the soil and are having high impact on the weeding operation. The weeder blades are made up of mild steel. Generally weeder blades are connected to a frame by means of bolt and nut. The blades are of two types and are used as weeder blades and tillers namely V and Lshaped blades. The V - shaped blades is used for weeding operation while the L- shaped blades used to loosen the soil before the V-shaped blades.

\subsubsection{Determination of the Drive Shaft Diameter}

The shaft was initially decided to be fabricated from ductile material (mild steel rod). Hence, the design was based on ductile material whose strength is controlled by maximum shear stress. For a shaft having little or no axial loading, the diameter of the shaft was obtained using the ASME code equation (ASME, 1995) given as:

$$
d^{3}=\frac{5.1}{T_{\max }}\left[\left(K_{m} M\right)^{2}+\left(K_{t} T\right)^{2}\right]^{\frac{1}{2}}
$$

Where: $-\mathrm{d}=$ diameter of the shaft; $\mathrm{mm}$

$\mathrm{M}=$ torsional moment; $\mathrm{Nm}$

$\mathrm{T}=$ bending moment; $\mathrm{Nm}$

$\mathrm{K}_{\mathrm{m}}=$ combined shock and fatigue factor applied to bending moment;

$\mathrm{K}_{\mathrm{t}}=$ combined shock and fatigue factor applied to torsional moment;

$\mathrm{T}_{\max }=$ maximum stress of steel; $\mathrm{MN} / \mathrm{m}^{2}$

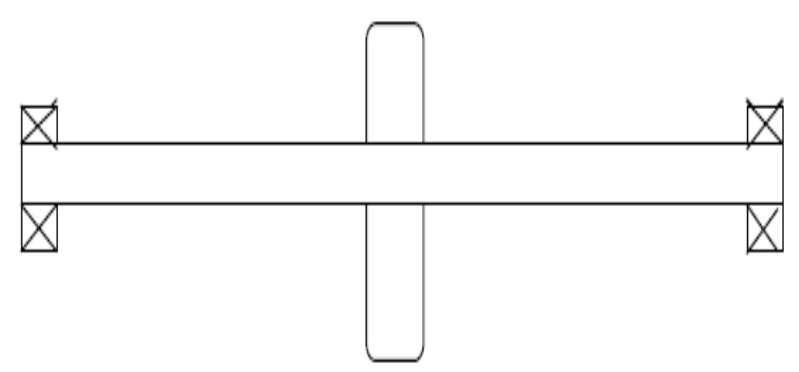

Fig.2. Tire and bearings arrangement on wheel shaft 
Torque on the shaft

Torsional strength of the shaft was considered by calculating the drive torque of rotating shaft which was subjected to both twisting and bending.

The weight on the wheels is $25 \mathrm{~kg}$

Power output of average human being $=0.76$ of $\mathrm{Hp}$

$$
\begin{aligned}
& =0.76 \times 0.746 \mathrm{KW} \\
& =0.56 \mathrm{KW}
\end{aligned}
$$

Torque on the shaft, $\mathrm{T}=25 \times 9.81 \times 0.15$

$$
=36.79 \mathrm{Nm}
$$

Bending moment on the shaft wheel

The reaction of forces on the driven wheel shaft is as shown below for vertical forces from figure above.

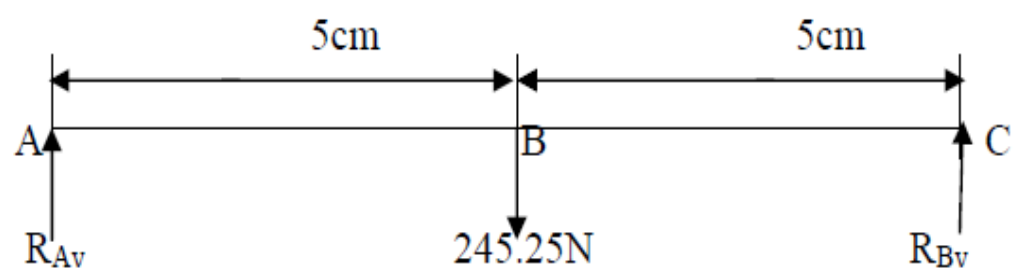

The forces on the shaft are arranged symmetrically

Therefore, $\mathrm{RAv}+\mathrm{RBv}=245.25 \mathrm{~N}$ if summed up vertically

Taking moment about point A

$(\operatorname{RBv} \times 0.1)-(245.25 \times 0.05)=0$

$0.1 \mathrm{RBv}-12.2625=0$

$0.1 \mathrm{RBv}=12.2625$

$\mathrm{RBv}=12.2625 / 0.1$

$\mathrm{RBv}=122.625 \mathrm{~N}$

$\mathrm{RAv}=245.25-122.625$

$\mathrm{RAv}=122.625 \mathrm{~N}$

Bending moment of the shaft for vertical loading:

Bending moment at $\mathrm{x}=0.05 \mathrm{~m}$ from $\mathrm{A}$

$122.65 \times 0.05=6.1325 \mathrm{Nm}$

Bending moment at $\mathrm{x}=0.10 \mathrm{~m}$ from $\mathrm{A}$ is zero 
Bending moment diagram

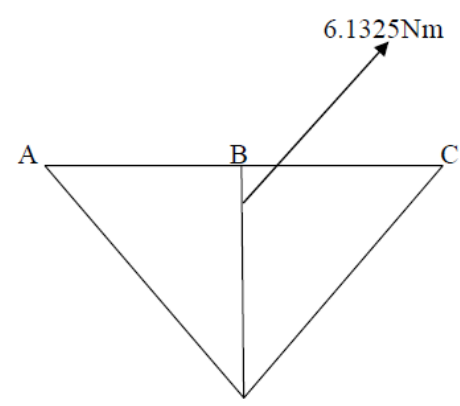

Resolving the forces horizontally

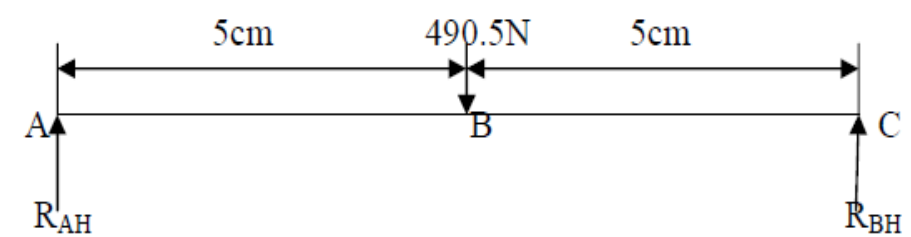

The forward driving force through wheel is $490.5 \mathrm{~N}$ horizontally

Resolving vertically,

$$
\mathrm{RAH}+\mathrm{RBH}=490.5 \mathrm{~N}
$$

Hence, $\mathrm{RAH}=\mathrm{RBH}=490.5 / 2=245.25 \mathrm{~N}$

Bending moment on the shaft due to horizontal forces:

Bending moment at $\mathrm{x}=0.05 \mathrm{~m}$ from $\mathrm{A}$

$$
245.25 \times 0.05=12.2625 \mathrm{Nm}
$$

Bending moment at $\mathrm{x}=0.10 \mathrm{~m}$ from $\mathrm{A}$ is zero

Bending moment diagram

$12.2625 \mathrm{~N}$

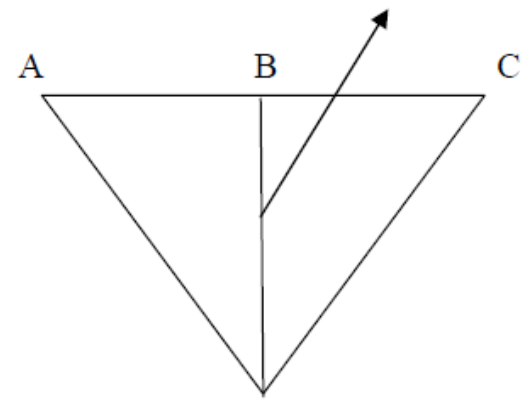

The total resultant component of the horizontal and vertical bending moment at $\mathrm{B}, \mathrm{M}$

$$
\begin{aligned}
M & =\sqrt{ } 6.1325^{2}+12.2625^{2} \\
& =\sqrt{ } 75190.585 \\
& =13.71 \mathrm{Nm}
\end{aligned}
$$


The shaft diameter can be calculated from the following formula with shock loading in the design of rotating shaft:

$\mathrm{d}^{3}=5.1 / \mathrm{T}_{\max } \sqrt{ }\left(\mathrm{K}_{\mathrm{m}} \mathrm{M}\right)^{2}+\left(\mathrm{K}_{\mathrm{t}} \mathrm{T}\right)^{2}$

$\mathrm{T}_{\max }=$ maximum stress of steel $=6000 \mathrm{Psi}=41.378 \times 106 \mathrm{~N} / \mathrm{m}^{2}$

$\mathrm{K}_{\mathrm{m}}=2 \& \mathrm{M}=13.71 \mathrm{Nm}$

$\mathrm{K}_{\mathrm{t}}=1.5$

$\mathrm{T}=36.79 \mathrm{Nm}$

$\mathrm{d}^{3}=5.1 / 41.378 \times 106 \sqrt{ }(2 \times 13.71)^{2}+(1.5 \times 36.79)^{2}$

$=7.595 \times 10-6$

$\mathrm{d}=(7.595 \times 10-6) \frac{1}{3}$

$\mathrm{d}=19.66 \mathrm{~mm}$

Hence, the shaft diameter that is $20 \mathrm{~mm}$ was suitable for the machine.

\subsection{Machine performance and evaluation}

Study on the field performance was carried out to obtain actual data on over all machine performance and work capacity in the actual field conditions. The field was prepared by local plough called Maresha followed by spike tooth harrow. Wheat was sown in row using Asella wheat row planter. The field trials were conducted at $100 \mathrm{~m}^{2}$ on farmer's field during the meher season of year 2009. The weeding operation was carried out in row-sown wheat at row-to-row spacing of $20 \mathrm{~cm}$. The plant and weed population was counted before and after the operation. The machine performance parameters such as weeding efficiency, plant damaged, actual field capacity, theoretical field capacity, field efficiency, and cost analysis of the weeder were determined as follows.

\subsubsection{Effective working depth}

The depth of cut of the weeder was measured in the field by measuring the depth of soil layer tilled by the weeder in a row. The depth of the weeding was measured by measuring scale in different rows at different places. Average of nine observations was taken as depth of weeding and expressed in $\mathrm{cm}$.

\subsubsection{Effective working width}

The width of cut of the weeder was measured in the field by observing the strip of soil and weeds cut in a row.

\subsubsection{Operation Speed}

To determine the travel speed of the machines during weeding operation, the time required for covering $10 \mathrm{~m}$ row length was recorded. Four measurements were recorded in each plot and average value was calculated. A digital stop watch was used to record the time in seconds to cover $10 \mathrm{~m}$ distance by weeder.

Speed $(\mathrm{km} / \mathrm{h})=\frac{\text { Dis } \tan c e(m)}{\text { Time }(\mathrm{s})} \times 3.6$ 


\subsubsection{Theoretical Field Capacity}

Theoretical field capacity of the weeder is the rate of field coverage that would be obtained if the weeder was performing its function $100 \%$ of the time at the rated forward speed and cover $100 \%$ of its rated width. It is expressed as hectare per hour and determined as follows (Kepner et al., 1978)

Theoretical field capacity $(\mathrm{km} / \mathrm{h})=\frac{S \times W}{10}$

Where,

$\mathrm{S}=$ speed, $\mathrm{km} / \mathrm{h}$

$\mathrm{W}=$ theoretical width, $\mathrm{m}$

\subsubsection{Actual field capacity}

The weeder was continuously operated in the field for the specific time period. Actual field capacity is the actual average rate of work coverage by the weeder, based upon the total field time. It is a function of the rated width of the machine, the percentage of rated width actually utilized, speed of the travel and the amount of field time lost during the operation. Actual field capacity is usually expressed as hectare per hour (Kepner et al., 1978).

$$
\text { Actual field capacity }(\text { ha } / h)=\frac{A}{T_{P}+T_{n}}
$$

Where,

$\mathrm{A}=$ area covered, ha

$\mathrm{Tp}=$ productive time, $\mathrm{h}$

$\mathrm{T}_{\mathrm{n}}=$ nonproductive time, $\mathrm{h}$

\subsubsection{Field efficiency}

It is the ratio of actual field capacity to theoretical field capacity, expressed as percent. It includes the effect of time lost in the field and the failure to utilize the full width of machine. It was calculated by using the following formula.

$$
\text { Field efficiency }=\frac{\text { Actual Field Capacity }}{\text { Theoretical Field Capacity }} \times 100
$$

\subsubsection{Damaged plant}

In order to determine the damaged plant, as a quality of work done at four places of each plot, metal frame of $1 \mathrm{~m} \times$ $1 \mathrm{~m}$ was thrown in the field purposely and the numbers of plants before and after weeding were counted. Then, the percentage of damaged plants was obtained by the following equation (Yadav and Pund, 2007):-

$q=\left[1-\left(\frac{Q}{P}\right)\right] \times 100$ 
Where: $-\mathrm{q}=$ plant damage per cent

$\mathrm{Q}=$ Number of plants in a $1 \mathrm{~m}^{2}$ area after weeding

$\mathrm{P}=$ Number of plants in a $1 \mathrm{~m}^{2}$ area before weeding

\subsubsection{Weeding efficiency}

It is the ratio between the numbers of weeds removed by the weeder to the number of weeds present in a unit area and is expressed as a percentage. The samplings were done by quadrant method, purposively selected of spots by a square quadrant of square meter (Tajuddin, 2006).

$W_{E}=\frac{w_{1}-w_{2}}{w_{1}} \times 100$

Where, $\mathrm{W}_{\mathrm{E}}=$ Weeding efficiency of the weeder $(\%)$,

$\mathrm{w}_{1}=$ Number of weeds counted per unit area before weeding operation

$\mathrm{w}_{2}=$ Number of weeds counted in same unit area after weeding operation

\section{Cost Estimation}

Estimation of annual and hourly operational costs of the weeder were based on capital cost of the weeder, interest on capital, cost of repairs and maintenance, labor cost, and depreciation. Cost of weeding operation performed for weeder was worked out on the basis of the prevailing input and fabrication price of the implements, machinery and rental wages of operator and labors required. The cost of operation of the weeder is divided into two heads known as fixed cost and variable cost. Fixed cost is independent of operational use while variable cost varies proportionally with the amount of use. (Kamboj et al, 2012).

The fixed cost of the weeder includes mainly depreciation and interest on the capital costs. Variable cost of the weeder mainly includes, repair and maintenances cost and wages. Cost of weeding operation for the weeder was calculated as Birr/ha. Operation cost of the weeder was calculated as follows:-

\subsection{Fixed cost}

\subsubsection{Depreciation}

It was a measure of the amount by which value of the machine decreased with the passage of the time. According to the Kepner et al. (2005), the annual depreciation was calculated as follows:-

$D=\frac{C-S}{L \times H}$

Where,

$\mathrm{D}=$ Depreciation per hour

$\mathrm{C}=$ Capital investments (Birr) 
$\mathrm{S}=$ Salvage value, $10 \%$ of capital investment (Birr)

$\mathrm{L}=$ Life of machine in hours or years

$\mathrm{H}=$ Annual operational hours of the weeder

\subsubsection{Interest}

Interest is calculated on the average investment of the machine taking into consideration the value of the machine in the first and last year. These are usually calculated on yearly basis. The annual interest on the investment can be calculated as follows (Kepner et al. (2005) :-

$I=\left(\frac{C+S}{2}\right) \times\left(\frac{i}{H}\right)$

Where

$\mathrm{I}=$ Interest per hour

$\mathrm{i}=$ interest on the investment $(\%)$ per year

\subsubsection{Variable cost}

\subsubsection{Repair and maintenance cost}

The repair and maintenance cost of the weeder was taken as $2.5 \%$ of the cost of the weeder (Kepner et al., 2005 and Kamboj et al.,2012).

$$
R M=\frac{C \times 2.5 \%}{H}
$$

Where:-

$\mathrm{RM}=$ Repair and maintenance cost per hour

$\mathrm{H}=$ Annual working hours of the weeder

\subsubsection{Wages of operator}

Wages are calculated based on actual wages of workers per day or hour.

\section{Total cost of weeding per hour}

The total cost of weeding per hour of the weeder was calculated from the summation of total fixed cost per hour and total variable cost per hour as follows.

Total Cost $/ \mathrm{h}=$ Fixed Cost per hour + variable Cost per hour

The operational cost of using the hoe and hand weeding was estimated and compared with the operational cost of the weeder. The operational cost components only.

Wages are calculated based on actual wages of workers per day or hour. 


\section{Experimental Design and Data Analysis}

The randomized complete block design was adopted in experimental field with two treatments and six replications. Three different types of implements and two soil types were used as treatments and replicated six times. Data were analyzed using GenStat $16^{\text {th }}$ edition statistical software by least significant difference (LSD) at $5 \%$ level of significance.

\section{Results and Discussions}

This chapter deals with the results and discussion for the conducting different experiments regarding weeding operations in wheat crop with mechanical weeder, manual and hoe weeding methods in sandy, loamy and clay soils. A trial was conducted at model farmer's wheat farm. The detail of results and discussion regarding objective are given below.

\subsection{Weeding efficiency}

The analysis of variance (ANOVA) revealed that the weeding method had significant effect $(\mathrm{p}<0.05)$ on weeding efficiency, whereas soil type and the interaction of weeding method and soil type had no significant effect $(\mathrm{p}>$ 0.05 ) on weeding efficiency. Table 1 show the effect of weeding methods, soil type and the combined effect of weeding methods and soil type on mean percent of weeding efficiency. The highest weeding efficiency was recorded for hand weeding $(98.00 \%)$, but it was not economical because of more labour intensive and time consuming. The lowest weeding efficiency was recorded for the weeder (81.67\%), however, besides uprooting the weeds loosen the soil between rows thus increasing air and water intake capacity. Similar finding were reported by Ramesan et. al., (2007) and Quadri A., 2010.

Table1. Effects of soil type and weeding methods on weeding efficiency (WE)

\begin{tabular}{|c|c|c|c|c|c|c|}
\hline \multirow{2}{*}{ Parameter } & \multicolumn{4}{|c|}{ Source of variation } & \multicolumn{3}{|c|}{$\begin{array}{c}\text { Measure of } \\
\text { differences }\end{array}$} \\
\cline { 2 - 5 } & Soil Type & \multicolumn{3}{|c|}{ Weeding Methods } & \multicolumn{2}{c|}{} \\
\cline { 2 - 5 } & Hoe & Hand & Weeder & LSD (5\%) & SE(M) \\
\hline $\begin{array}{c}\text { Weeding } \\
\text { Efficiency } \\
(\%)\end{array}$ & CLS & $87.67^{\mathrm{b}}$ & $97.67^{\mathrm{a}}$ & $84.67^{\mathrm{c}}$ & & \\
\cline { 2 - 5 } & CL.00 & $98.00^{\mathrm{a}}$ & $81.67^{\mathrm{d}}$ & 6.472 & 2.054 \\
\hline
\end{tabular}

Means followed by the same letter (or letters) do not have significant difference at $5 \%$ level of probability

\subsection{Damaged plants}

The analysis of variance (ANOVA) revealed that the weeding method had significant effect $(\mathrm{p}<0.05)$ on percentage of plant damage, whereas soil type and the interaction of weeding method and soil type had no significant effect $(\mathrm{p}>0.05)$ on percentage of plant damage. Table 2 show the effect of weeding methods, soil type and the combined effect of weeding methods and soil type on mean percentage of plant damage. The minimum percentage of plants damaged was $(0.250 \%)$ in hand weeding, while the maximum percentage of plant damaged 
Asian Journal of Basic Science \& Research Volume 3, Issue 1, Pages 85-100, January-March 2021

$(1.853 \%)$ respectively by weeder. The higher damaged of plant in case of the weeder as compared to hoe and hand weeding methods may be due to higher travel speed. These results are in agreement with Alizadeh M.R. (2011).

Table 2. Effects of soil type and weeding methods on plant damage (Pd)

\begin{tabular}{|c|c|c|c|c|c|c|}
\hline \multirow{2}{*}{ Parameter } & \multicolumn{4}{|c|}{ Source of variation } & \multicolumn{2}{|c|}{$\begin{array}{c}\text { Measure of } \\
\text { differences }\end{array}$} \\
\cline { 2 - 5 } & \multirow{2}{*}{ Soil Type } & \multicolumn{2}{|c|}{ Weeding Methods } & \multicolumn{2}{|c|}{} \\
\cline { 2 - 5 } & & Hoe & Hand & Weeder & LSD (5\%) & SE(M) \\
\hline \multirow{2}{*}{$\begin{array}{c}\text { Plant } \\
\text { Damage }\end{array}$} & SLS & $0.413^{\mathrm{c}}$ & $0.357^{\mathrm{c}}$ & $1.413^{\mathrm{b}}$ & & \\
\cline { 2 - 5 } & CLS & $0.483^{\mathrm{c}}$ & $0.250^{\mathrm{cd}}$ & $1.853^{\mathrm{a}}$ & 0.3769 & 0.1196 \\
\hline
\end{tabular}

Means followed by the same letter (or letters) do not have significant difference at 5\% level of probability

\subsection{Operating speed}

To determine the travel speed of the machines during weeding operation, the time required for covering $10 \mathrm{~m}$ row length was recorded. Four measurements were recorded in each plots and $1.55 \mathrm{~km} / \mathrm{h}$ average value was recorded.

\subsection{Actual Field Capacity}

The field capacity of developed weeder was calculated by selecting a respective three plots of size $10 \times 10 \mathrm{~m}$ for each soil types. The weeder was operated in these plots and the different observations were recorded. The analysis of variance (ANOVA) revealed that the weeding method had significant effect $(\mathrm{p}<0.05)$ on field capacity, whereas soil type and the interaction of weeding method and soil type had no significant effect ( $p>0.05)$ on field capacity. Table 3 show the effect of weeding methods, soil type and the combined effect of weeding methods and soil type on mean actual field capacity. The maximum field capacity $(0.023067 \mathrm{ha} / \mathrm{h})$ was obtained with weeder followed by hand weeding which gave field capacity of $(0.007533 \mathrm{ha} / \mathrm{h})$, and the minimum field capacity obtained in case of hoe weeding, however, the hoe weeding methods besides killing the weeds loosen the soil between rows thus increasing air and water intake capacity. Similar finding were reported by Shiru (2011) at rice field.

Table 3. Effects of soil type and weeding methods on Actual Field Capacity (AFC)

\begin{tabular}{|c|c|c|c|c|c|c|}
\hline \multirow{2}{*}{ Parameter } & \multicolumn{4}{|c|}{ Source of variation } & \multicolumn{2}{c|}{ Measure of differences } \\
\cline { 2 - 5 } & \multirow{2}{*}{ Soil Type } & \multicolumn{3}{|c|}{ Weeding Methods } & \multicolumn{2}{c|}{} \\
\cline { 2 - 6 } & Hoe & Hand & Weeder & LSD (5\%) & SE(M) \\
\hline $\begin{array}{c}\text { Actual } \\
\text { Field } \\
\text { capacity }\end{array}$ & SLS & $0.007400^{\mathrm{c}}$ & $0.007533^{\mathrm{c}}$ & $0.023067^{\mathrm{a}}$ & & \\
\cline { 2 - 5 } & CLS & $0.007133^{\mathrm{d}}$ & $0.007333^{\mathrm{e}}$ & $0.022800^{\mathrm{b}}$ & 0.0004821 & 0.0001530 \\
\hline
\end{tabular}

Means followed by the same letter (or letters) do not have significant difference at $5 \%$ level of probability 


\subsection{Field Efficiency}

Table 4. Field efficiency

\begin{tabular}{|c|c|c|c|c|c|}
\hline \multirow{2}{*}{$\begin{array}{l}\text { Weeding } \\
\text { methods }\end{array}$} & \multicolumn{2}{|c|}{$\begin{array}{l}\text { Actual field capacity } \\
\qquad\left(\mathrm{hah}^{-1}\right)\end{array}$} & \multirow{2}{*}{$\begin{array}{c}\text { Theoretical field } \\
\text { capacity }\end{array}$} & \multicolumn{2}{|c|}{ Field Efficiency (\%) } \\
\hline & $\begin{array}{c}\text { Sandy loam } \\
\text { soil }\end{array}$ & $\begin{array}{c}\text { Clay loam } \\
\text { soil }\end{array}$ & & Sandy loam soil & $\begin{array}{c}\text { Clay loam } \\
\text { soil }\end{array}$ \\
\hline Weeder & 0.0231 & 0.0228 & 0.0279 & 82.79 & 81.72 \\
\hline Hoe weeding & 0.0074 & 0.0071 & nd & nd & nd \\
\hline Hand weeding & 0.0075 & 0.0073 & nd & nd & nd \\
\hline
\end{tabular}

$*_{n d-}$ no data*

The field efficiency of the weeder is the ratio of useful working to the total working time. The mean values of field efficiency of the weeder were 82.79 and $81.72 \%$ at sandy loam and clay loam soil respectively. The data in Table 4 , revaled that the weeder has the highest field efficiency $(82.79 \%)$ at sandy loam soil followed by clay loam soil $(81.72 \%)$, this means the weeder can work very effective on the sandy loam soil. Clay loam soil has the least percentage because of the fertility of the soil which allow deep root of the soil, making some weeds to bend and which do not allow the cutting edge to cut them. In sandy soil, the soil is loose and the roots of the weeds are not so deep for the cutting edge to lift them. Similar finding were reported by Quadri A., 2010.

\subsection{Labour requirement in different weeding methods}

Results in table 5 shows the labour required for different weeding methods and labour saving per hectare as compared to hoe and hand weeding method.

Table 5: Labour required in different weeding methods $\left(\right.$ man-hha $\left.{ }^{-1}\right)$ at different soil types

\begin{tabular}{|c|c|c|c|c|}
\hline Weeding methods & $\begin{array}{c}\text { Labour requirement } \\
(\mathbf{m a n}-\mathbf{h} / \mathbf{h a})\end{array}$ & $\begin{array}{c}\text { Man } \\
(\text { Birr/ h) }\end{array}$ & $\begin{array}{c}\text { Labour cost } \\
(\text { Birr/ha })\end{array}$ & $\begin{array}{c}\text { Labour saving } \\
(\boldsymbol{\%})\end{array}$ \\
\hline Weeder & 87 & 12.50 & 1087.50 & - \\
\hline Hoe weeding & 141 & 12.50 & 1762.50 & 38.30 \\
\hline Hand weeding & 137 & 12.50 & 1712.50 & 36.50 \\
\hline
\end{tabular}

Table 5 revealed that the minimum time for controlling weeds was (87 man-h/ha) for mechanical weeder and maximum time for controlling weeds was (141 man-h/ha) for hoe weeding. Khan and Diesto (1987) reported that, manual weeding of rice in one hectare requires on an average of 120 man-h/ha. Saving in time for weeding operation mechanical weeder were 38.30 and $36.50 \%$ as compared to hoe and hand weeding method respectively. In case of hoe weeding the labour requirement was almost similar to hand weeding methods. Hoe and hand 
weeding methods are costly and labour intensive. These involve considerable time and labours. Limitation of labour at the time of weeding is becoming day to day a major constraint; therefore mechanical weeder could be selected to save time as well as labour.

\subsection{Potential Yield}

Potential yield was determined from $1 \mathrm{~m}^{2}$ area. Five random observations were taken from each plot and the seeds were thoroughly separated from straw and the weight of seeds were recorded and expressed in $\mathrm{kg} \mathrm{ha}^{-1}$. The analysis of variance (ANOVA) revealed that the soil had significant effect $(\mathrm{p}<0.05)$ on potential, whereas weeding method and the interaction of weeding method and soil type had no significant effect $(\mathrm{p}>0.05)$ on potential yield. Table 6 show the effect of weeding methods, soil type and the combined effect of weeding methods and soil type on mean potential yield.

Table 6. Effects of soil type and weeding methods on potential yield (PY)

\begin{tabular}{|c|c|c|c|c|c|c|}
\hline \multirow{2}{*}{ Parameter } & \multicolumn{4}{|c|}{ Source of variation } & \multicolumn{2}{c|}{ Measure of differences } \\
\cline { 2 - 5 } & \multirow{2}{*}{ Soil Type } & \multicolumn{3}{|c|}{ Weeding Methods } & & \\
\cline { 2 - 5 } & & Hoe & Hand & Weeder & LSD (5\%) & SE(M) \\
\hline $\begin{array}{c}\text { Potential } \\
\text { yield(Qti/ha) }\end{array}$ & SLS & $91.0^{\mathrm{a}}$ & $80.1^{\mathrm{b}}$ & $92.5^{\mathrm{a}}$ & \multirow{2}{*}{11.16} & 3.54 \\
\cline { 2 - 5 } & CLS & $73.1^{\mathrm{c}}$ & $65.3^{\mathrm{d}}$ & $70.1^{\mathrm{c}}$ & & \\
\hline
\end{tabular}

Means followed by the same letter (or letters) do not have significant difference at $5 \%$ level of probability

\subsection{Cost Analysis}

The cost of weeder operation is the sum of fixed and variable cost. The total cost of weeding was obtained from all weeder operation and labor cost for weeding whereas in hoe and hand weeding the total cost of operation is just related to labor cost. Annual operation of the weeder was considered as 160 hour based on 20 days actual annual use in wheat field and daily 8 hour useful operation. Annually coverage area was determined by multiplication of the effective field capacity and annual hours of operation. In hoe and hand weeding, the total cost of operation is only related to the labour cost.

The initial cost of mechanical weeder is high by which more fixed cost was associated with weeder than the other weeding methods. The unit cost of the developed mechanical weeder was determined by calculating the cost of different components and their fabrication cost as given in Appendix table B1, B2 and B3. Table 7 shows that only operational cost of weeding in wheat crop for one hectare. The lowest weeding cost was associated with mechanical weeder (1087.50 Birr/ha). The weeding cost of mechanical weeder was reduced by 38.30 and $36.50 \%$, respectively as compared to hoe and hand weeding methods. Similar findings were also reported by Goel et al. (2008); Remesan et al. (2007); Tajuddin, (2009) and Parida (2002). These studies showed that selection of a method for controlling weed has significant role in the reduction of cost. The hand weeding method is not economical, because of costly weeding, difficulty of performance and limitation of labour at the proper time. 
Table 7. Weeding cost in different weed control methods.

\begin{tabular}{|c|c|c|c|}
\hline Weeding methods & $\begin{array}{c}\text { Labour input } \\
\text { (Man-h/ha) }\end{array}$ & $\begin{array}{c}\text { Total operational } \\
\operatorname{cost}(\mathrm{birr} / \mathrm{ha})\end{array}$ & $\begin{array}{c}\text { Saving in cost of } \\
\text { Weeding (\%) }\end{array}$ \\
\hline Hand weeding & 137 & $1,712.50$ & 36.50 \\
\hline Hoe weeding & 141 & $1,762.50$ & 38.30 \\
\hline Mechanical weeder & 87 & $1,087.50$ & - \\
\hline
\end{tabular}

\section{Summary and Recommendations}

\subsection{Summary}

The weeding methods included were hand weeding, Hoe weeding and weeder. The performance of the weeder was compared with the hand and hoe weeding. Different performance parameters such as field capacity, field efficiency, travel speed, labour required, damaged plant, weeding efficiency, potential yield and cost of operation were observed. Based on the results of various experiments conducted the following summaries were drawn.

* It was imagined that mechanizing the manual weeding operation could displace labour force and which could be used in other productive activities that could lead to increased productivity and can solve labourer scarcity to a large extent.

* The damaged plant percentages was found to be maximum in weeder $(1.853 \%)$ due to higher speed of operation, and damaged plant percentages was found to be minimum in hand weeding $(0.250 \%)$.

* The weeding efficiency was found highest (98\%) in hand weeding, but it is not economical due to high labour requirement and cost of operation. The lowest (81.67\%) weeding efficiency was found in weeder.

* The field capacity was found to be maximum $(0.0231 \mathrm{ha} / \mathrm{h})$ in weeder and minimum $(0.0071 \mathrm{ha} / \mathrm{h})$ in hoe weeding.

* Field efficiency of the weeder was found to be maximum (82.79\%) at sandy loam soil and minimum $(81.72 \%)$ at clay loam soil.

* The minimum time required for controlling weeds was related to the weeder ( 87 man-h/ha) and maximum time required for controlling weeds was in hand weeding (141 man-h/ha) and weeding time saving in weeder was reduced by 38.30 and $36.50 \%$, respectively as compared to hoe and hand weeding method .

* The operational cost of weeding in wheat crop was maximum in hoe weeding (1762.50 $\left.\mathrm{Birr}^{-1} \mathrm{ha}^{-1}\right)$ whiles the minimum was in weeder (1087.50 $\left.\mathrm{Birr} \mathrm{ha}^{-1}\right)$.

\subsection{Recommendations}

Through observation, this project work was good for local farmers and small scale agro-base industries that need a better treatment and operations carried out on farms. Possible future improvements to the design could include:- 
Asian Journal of Basic Science \& Research Volume 3, Issue 1, Pages 85-100, January-March 2021

(1) Possibility to reduce power requirement to push the machine with engine which can make it to perform better.

(2) For large scale crops production, there should be provision of width can be increased so that it can work on different rows of the farm at the same time.

\section{Declarations}

\section{Source of Funding}

This research did not receive any specific grant from funding agencies in the public, commercial, or not-for-profit sectors.

\section{Competing Interests Statement}

The authors declare no competing financial, professional and personal interests.

\section{Consent to participate}

Not Applicable

\section{Consent for publication}

We declare that we consented for the publication of this research work.

\section{Availability of data and material}

Authors are willing to share data and material according to the relevant needs.

\section{Reference}

Alizadeh M. R. (2011). Field performance evaluation of mechanical weeders in the paddy field in Scientific Research and Essays, Vol. 6(25), pp. 5427-5434.

Behera BK (1996). Performance evaluation of manual weeder for paddy crop in Orissa, India. AMA, Agricultural Mechanization in Asia, Africa and Latin America 27(3) 20 - 22.

Bhavin R, Khardiwar MS, Kumar S \& Yaduvanshi BK (2016). Performance evaluation of manual operated single row weeder for groundnut crop. International Journal of Agricultural Science and Research 6(3).

Islam, M. S. and Haq, K. A. 1985. Performance of indigenous hand weeders in Bangladesh. AMA. 16(4): 47-50.

Khan, A. V. and Diesto, M. 1987. Push type cono-weeder for small paddy farms. Investigation Intelligence. 23(3): 236-237.

Oni, K.C. (1990). Performance Analysis of a Ridge Profile Weeder. Proceeding of Nigerian Society of Agricultural Engineers. 3: 189-199.

Quadri, adegbemi wasiu, 2010. Department of agricultural engineering college of engineering university of agriculture abeokuta design, construction and testing of manually operated weeder (thesis). 
Remesan, R., Roopesh, M.S., Remya, N. and Preman, P.S. 2007 "Wet Land Rice Weeding- A Comprehensive Comparative Study from South India". Agricultural Engineering International: the CIGR Ejournal. Manuscript PM 07 011. Vol. IX.

Shiru, J.J. 2011. Design and development of a push-pull mechanical weeder for farmer's use. The Nigerian Academic Forum, 21(1).

Tajuddin, A. 2006. Design, development and testing of engine operated weeder. Agricultural Engineering Today, $30(5,6): 25-29$.

Yadav, R. and Pund, S. (2007). Development and ergonomic evaluation of manual weeder. Agricultural Engineering International: the CIGR Ejournal. Manuscript PM 07022 Vol. IX October. 